\title{
AGRICULTURE AS AN UNEMPLOYMENT BUFFER: THE CASE OF THE TOURISM COLLAPSE IN ANDALUSIA
}

\author{
$\underline{\text { Olexandr Nekhay }}^{a *}$, Roberto Roson $^{\text {a } b}$ \\ ${ }^{a}$ Universidad Loyola Andalucía (Sevilla y Córdoba). ${ }^{b}$ Università Ca' Foscari Venezia, Italy.
}

\section{Summary}

The COVID19 pandemic has had a strong economic impact on the different productive sectors.. However, the effects have been very unevenly distributed. Some industries, most notably those related to tourism, suffered the most, whereas some others were only marginally affected, or even experienced some expansion. Focusing on the regional economy of Andalusia, this study employs a computable general equilibrium model, to investigate the structural adjustment process, triggered by the sudden drop in tourism demand, generated by the mobility restrictions introduced in 2020. The model highlights how variations in relative prices could have allowed the agricultural sector to partly compensate the macroeconomic shock, in particular by absorbing some of the additional unemployment.

Key words: CGE modelling, COVID-19, Agricultural employment, Andalusia, regional economy.

\section{Introduction and objectives}

The economic crisis induced by the COVID-19 pandemic has negatively affected many economic sectors in Andalucía, bringing about a decline of Andalusian GDP by 10.3\% in 2020 (IECA, 2021). The service industries related to tourism were among the most badly affected. On the other hand, the agricultural sector was one of the least affected, in terms production levels, value added and employment.

Higher salaries offered by service industries normally pull workers out of agricultural employment. However, in 2020 the mechanism seems to have worked the reverse way.

This research aims at numerically simulate and analyse the general equilibrium process of reallocation of production and employment out of tourism and into agriculture.

To this end, a newly developed General Equilibrium Model of Andalusia (MEGA), which can fully trace the circular flow of income inside the economic system, has being used (Roson, 2021). Parameters of the model are calibrated, based on a social accounting matrix of Andalusia, estimated for the year 2016 (Roson and van der Voorst, 2020).

The exercise is a classic comparative static one, where an initial (general) equilibrium is shocked, and a counterfactual equilibrium is generated, in the absence of any explicit time dimension. The shock here is the cut in tourism external income inflow, which is exogenous in the model. The results should by no means be interpreted as a realistic measure of impacts, though, but rather as a hypothetical ceteris paribus evaluation. Indeed, we are not considering other impacts related to the pandemic in Andalusia or elsewhere. Also, we are not considering non-market adaptation or policy responses, even when they would be semiautomatic (like in the case, e.g., of higher unemployment benefits).

\section{Methodology}

The main data source for the modeling exercise presented in this paper is a Social Accounting Matrix (SAM) for the Spanish region of Andalusia (Roson and van der Voorst, 2020). Structural parameters of the general equilibrium model have been calibrated on the SAM data, therefore the design of the CGE model has been influenced by the available information.

The Andalusian SAM considers three regions (Andalusia, Rest of Spain, Rest of the World), 87 produced goods and services and 84 industries (an industry can produce multiple goods, whereas a good may be produced by different industries), two household categories (residents, non-residents), a public sector and an investment sector. It also considers eight classes of primary factors, where four of them denote categories of labor.

The general equilibrium model, based on the SAM, takes the form of a large non-linear system of equations, including market balances, budget constraints and accounting identities.Like in all Walrasian general equilibrium models, money does not play any role and the system can only determine relative prices, from where all remaining endogenous variables are derived.

Some assumptions in the model depart from the typical CGE setting. All primary factors, for instance, are not perfectly mobile. A CET function is used to allocate the factors among the various productive activities, in such a way that more (but not all) factors get employed where their returns are relatively higher.

The model accounts for the fact that Andalusian factors may be employed outside the region, whereas not all factors employed in Andalusian industries are owned by regional citizens. However, there is no interregional migration of factors. 
Average salaries for labor factors are endogenously determined through a wage curve, meaning that the model computes variations in employment (or unemployment) by worker category. This model feature is of fundamental importance in a region where unemployment rates are very high. A wage curve is an empirical relationship, justifiable because of the existence of trade unions or efficiency wages, linking wages to unemployment rates. It therefore plays the role of a labor supply curve. The key elasticity parameter (-0.06) has been estimated for Andalusia by Bande et al. (2012) and it is adopted here for all labor categories.

For the specific exercise presented in this work, the shock is applied to the money inflow spent in the region by non-residents, distinguished by origin (rest of Spain, rest of the world). The magnitude of the shock, which is of course a reduction, can be estimated by considering some preliminary information on touristic flows in the year 2020. The year includes very different sub-periods: when the region was totally open (first two months), totally closed, open for national travelers, partially open to international travelers with movement limitations (fewer flights, more controls and mobility constraints).

Expenditure by tourists coming to Andalusia from the rest of Spain fell by $25 \%$ in the first quarter of 2020 , compared to the previous year. The year-on-year differences for the second and third quarter of 2020 are $85 \%$ and $-21 \%$ (INE 2021a). The relatively better performance in the summer reflects the easing of mobility restrictions over that season. Tourist expenditure from the EU and the rest of the world decreased even more in year-on-year terms, by $20 \%, 99 \%$ and $79 \%$ respectively in the first, second and third quarter of 2020 (INE 2021b). Based on these data, we find that expenditure by international tourists fell by $75 \%$ and we correspondingly reduced the incoming revenue by the same amount in the simulation. Expenditure by tourists from the rest of Spain falls slightly less, thus we applied a shock to consumption expenditure from the rest of Spain of $-70 \%$.

\section{Results}

Although the model produces results for many economic variables, we focus here on the effect of the tourism demand shock on agricultural employment.

Because of the drop in tourism demand only, the Andalusian GDP declines by $-3.89 \%$. The system moves toward a new equilibrium, where some sectors shrink, but a few others expand. Among the losers are those industries related to transport and tourism, whereas among winners there are: construction, ITC and agriculture. Table 1 provides more detail about the percentage change in gross output for the eight industries inside the agricultural sector.

Table 1. Change in output volumes of agricultural products in Andalusia

\begin{tabular}{|l|c|}
\hline Agriculture related activities & \% change \\
\hline Horticulture, fruts \& flowers cultivation & 0.16 \\
\hline Grape and olive cultivation & -0.07 \\
\hline Other agricultural crops and services & 0.37 \\
\hline Livestock production and hunting & -0.53 \\
\hline Forestry and logging & 2.20 \\
\hline Fisheries and aquaculture & -3.57 \\
\hline Production of fats and oils & -0.90 \\
\hline Production of dairy products & -2.74 \\
\hline
\end{tabular}

Source: own elaboration.

There are four categories of workers in the model. Figure 1 displays the changes in total employment for the four classes. The overall unemployment rate in the region is found to increase by $+1.84 \%$, yet agricultural and non-skilled employment is found to rise $(+4.1 \%)$. 


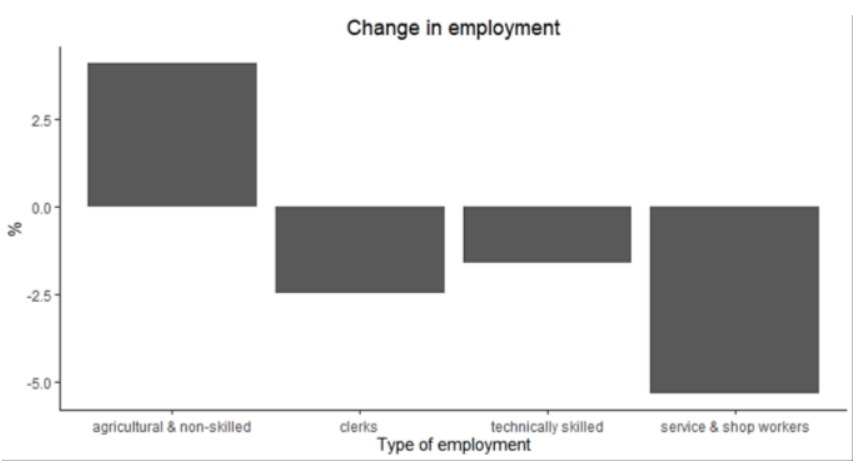

Figure 1. Change in employment by worker category. Source: authors' simulation

Table 2 provides more detail about the variation in employment levels for the eight agricultural industries.

Table 2. Change in the employment of agricultural workers by activity

\begin{tabular}{|l|c|}
\hline Agriculture related activities & \% change \\
\hline Horticulture, fruts \& flowers cultivation & 0.53 \\
\hline Grape and olive cultivation & 0.37 \\
\hline Other agricultural crops and services & 0.88 \\
\hline Livestock production and hunting & 0.59 \\
\hline Forestry and logging & 2.43 \\
\hline Fisheries and aquaculture & -1.66 \\
\hline Production of fats and oils & 0.07 \\
\hline Production of dairy products & -1.30 \\
\hline
\end{tabular}

Source: own elaboration.

The allocation of workers among the various industries is driven by changes in relative wages. Overall, an index of wages in the regional economy is found to lower by only $-0.34 \%$, because of the wage rigidity imposed by the wage curve assumption. Nonetheless, inside the various industries (relative) wages vary quite substantially. For instance, non-skilled workers in bars and restaurants are paid $-14 \%$ less. Workers in personal domestic services get a modest increase $(+0.54 \%)$, but those in the construction industry a more significant one $(+6.48 \%)$. The impact on wages of non-skilled workers for the various agricultural industries is reported in Table 3.

Table 3. Change in wages of non-skilled workers in agriculture

\begin{tabular}{|l|c|}
\hline Agriculture related activities & \% change \\
\hline Horticulture, fruts \& flowers cultivation & -3.4 \\
\hline Grape and olive cultivation & -3.5 \\
\hline Other agricultural crops and services & -3.1 \\
\hline Livestock production and hunting & -3.3 \\
\hline Forestry and logging & -1.9 \\
\hline Fisheries and aquaculture & -5.2 \\
\hline Production of fats and oils & -3.8 \\
\hline Production of dairy products & -4.9 \\
\hline
\end{tabular}

Source: own elaboration.

The key insight here is that wages decline in all agricultural industries, but much less so than in the services. This reallocates labour resources away from the services, towards agriculture and other labour-intensive industries (e.g., construction).

This is confirmed by the results shown in Table 4, displaying the sectors associated with the highest relative increase in the demand for non-skilled workers. These sectors account for 55.9\% of the total employment for this category of workers. Please notice that the changes are in normalized percentage terms. As it can 
be seen that construction is by far a most relevant activity for the employment of workers. The second relevant activity "Repair and installation of machinery and equipment" employs much less workers.

Table 4. Top 5 economic activities with the biggest increase in the demand for agricultural \& non-skilled workers normalized changes

\begin{tabular}{|l|l|}
\hline Activities & $\%$ change \\
\hline Construction & 3.70 \\
\hline Repair and installation of machinery and equipment & 0.23 \\
\hline Manufacture of fabricated metal products, except machinery and equipment & 0.11 \\
\hline Public administration and defence; compulsory social security & 0.09 \\
\hline Public education & 0.08 \\
\hline
\end{tabular}

Source: own elaboration.

\section{Conclusions}

We used a computable general equilibrium model to numerically replicate the adjustment process occurring in the Andalusian economic system, as a response to the dramatic fall in tourism expenditure, associated with the COVID-19 pandemic. Specifically, we elaborated on the result showing that employment for agricultural and non-skilled workers would have increased.

How much of this effect is due to the (re-)absorption of unemployed workers in agriculture, expelled from the tourism sector? We found that this absorption effect is present but quite limited, with significant differences among agricultural industries. Forestry and logging is the industry with the largest increase in employment. However, other sectors in the regional economy, most notably construction, play a more significant role as labour buffers, thereby dumbing the negative consequences of the tourism demand drop on employment.

\section{References}

Bande, R., Fernández, M., and Montuenga, V. (2012). Wage flexibility and local labour markets: a test on the homogeneity of the wage curve in Spain. Investigaciones Regionales-Journal of Regional Research, (24), 175-198.

Junta de Andalucía (2020). El sector agrario y pesquero en Andalucía. Junio 2020. Consejería de Agricultura, Ganadería, Pesca y Desarrollo Sostenible. Secretaria General de Agricultura, ganadería y Alimentación.

IECA (Instituto de Estadística y Cartografía de Andalucía) (2021). Estadisticas de sintesis.

Instituto Nacional de Estadística. (2021a). Resultados nacionales: Destino principal de los viajes (extranjero/comunidad autónoma) Viajes, pernoctaciones, duración media y gasto por destino principal. Retrieved from: https://www.ine.es/jaxiT3/Datos.htm?t=12434

Instituto Nacional de Estadística. (2021b). Gasto Turístico : Resultados por comunidades autónomas Gasto de los turistas internacionales según comunidad autónoma de destino principal. Retrieved from : https://www.ine.es/jaxiT3/Datos.htm?t=10839

Pyatt, G., and Round, J. I. (1985). Social accounting matrices: A basis for planning (No. 9950, p. 1). The World Bank.

Roson, Roberto, and Camille Van der Voorst (2020). "A Social Accounting Matrix for Andalusia." University Ca'Foscari Venice, Dept. of Economics Research Paper Series No 22-2020.

Roson, Roberto (2021). “The MEGA Regional General Equilibrium Model”. University Ca'Foscari Venice, Dept. of Economics Research Paper Series No 6 (2021). 